\title{
Sylwia JASKUŁA
}

Państwowa Wyższa Szkoła Informatyki i Przedsiębiorczości w Łomży sylwia.jaskula@poczta.onet.pl

\section{Leszek KORPOROWICZ}

Uniwersytet Jagielloński

leszek.korporowicz@poczta.onet.pl

\section{KULTURY NARODOWE \\ W PROCESIE WIRTUALIZACJI}

\section{ABSTRACT National cultures in the process of virtualization}

The pace of technological development and the associated development of new instruments of communication resulted in a number of consequences that are essential to the very concept of culture and its transformation. Today's world of virtualization and mediatization of cultures cannot be perceived as inert or static, but should be seen as a process; not as a rigid quasi-object, but as a continuous and endless stream of variable events. The processes occurring in it, or changes that vary in speed, intensity, rhythm and pace, are becoming the basis for the emergence of new forms of national culture including an unprecedented structure, roles, functions, or intensity. Starting from mobile identities, often created in isolation from one's own self and free from the usually strict control of the ego and superego, through mobile relations (relationships), and culminating with virtual forms of existence (participation) in the modern, national cultures.

Słowa kluczowe: kultura narodowa, grupa etniczna, przestrzeń wirtualna, syntagma kulturowa

Key-words: national culture, ethnicity, virtual space, virtualization of culture 


\section{WSTĘP}

Wirtualność stała się znamieniem współczesności. Użyte przez Zygmunta Baumana określenie naszej epoki jako „płynnej nowoczesności” nabiera szczególnego znaczenia, jeśli wymiar „plynności” odniesiemy do przestrzeni wirtualnej. Ten nowy obszar wyznaczany tempem rozwoju technologii informacyjno-komunikacyjnej, naznaczony „odcieleśnioną” obecnością współczesnego człowieka, coraz częściej i szerzej winien być obejmowany refleksją w kontekście jego odmienności, a jednocześnie silnego wkomponowania w nowe rodzaje „realności” kultury współczesnej. Rozumienie samej przestrzeni wirtualnej oraz procesów w niej zachodzących wymaga wszakże równie innowacyjnego podejścia do jego natury pozbawionej aspektów fizyczności. Przestrzeń ta staje się kolejnym, piątym wymiarem ${ }^{1}$ rzeczywistości, jaką odkrywa i jakiej doświadcza współczesny człowiek wraz z jej różnorodnymi aplikacjami w życiu indywidualnym i zbiorowym ${ }^{2}$. Współcześnie jesteśmy świadkami coraz bardziej dynamicznego przenoszenia wielorakich komponentów ze świata realnego do nowego obszaru bytu człowieka. Sieć wirtualna jest coraz szerzej zagospodarowywana, w tempie, jakiego dotychczas w całej historii ludzkości nigdy nie udało się uzyskać. Prawdopodobnie ten właśnie impet przeobrażeń staje się główną przyczyną nienadążania rzeczywistości „realnej” za zmianami, ale i potrzebami człowieka w przestrzeni wirtualnej. Dotychczasowe doświadczenia pokazują, iż nowo wygenerowany obszar jest zaniedbywany i nieczęsto obejmowany działaniami mającymi na celu wprowadzenie celowości, ładu i systematyczności. Z drugiej strony wiele różnych aspektów tej nowej rzeczywistości zachowuje swój niezwykle zmienny, niedookreślony i „płynny” charakter, trudno uchwytny w konceptualnej, metodycznej analizie. Trudności te z pewnością owocować będą już w najbliższej przyszłości wieloma innowacjami teoretycznymi, które wymuszać będzie sama rzeczywistość, zmuszając jednocześnie do napisania od nowa wielu słowników z dziedziny nauk społecznych i humanistycznych, które powstały w epoce klasycznego definiowania przestrzeni, komunikacji, kultury oraz równie klasycznie rozumianych grup społecznych, jak naród czy grupa etniczna.

Współczesna przestrzeń, szczególnie wirtualna, która wymyka się opisowi w kategoriach fizycznej odległości jej nośników, staje się częścią dynamicznych i w istotny sposób „odcieleśnionych” procesów komunikacji. Metaforyka tej przestrzeni łamie potoczność jej rozumienia, nie da się bowiem ująć jej parametrycznie, posługując się wyłącznie kategoriami fizycznymi. W wirtualnej przestrzeni człowiek jest zawieszony pomiędzy tym, co realne, a tym, co wirtualne, ale co zaczyna stanowić nowy rodzaj realności o bardzo silnym wpływie na wiele obszarów jego najzupełniej realnego życia. Następuje tu reinterpretacja i swoiste rekodowanie funkcji i znaczenia sfery fizycz-

1 Przyjmując, iż dotychczas interpretowaliśmy świat w czterech wymiarach, z czego trzy wskazywały na szerokość, długość i głębokość, zaś czwarty - rozszerzony przez Alberta Einsteina - czas.

2 S. Jaskuła, Tożsamośća piąty wymiar w przestrzenimiędzykulturowej, [w:] Tożsamośćw wielokulturowym kontekście, red. L. Dyczewski, K. Jurek, Lublin 2013, Tożsamość Osób, Zbiorowości, Instytucji, 13. 
nej w społecznej, kulturowej i etnicznej rzeczywistości człowieka. Leah P. Macfadyen, kanadyjska badaczka procesów wirtualizacji etniczności, uważa jednak, iż nie oznacza to zaniku elementów etnicznych w przestrzeni globalizujących się interakcji, a jedynie istotną zmianę ich formy ${ }^{3}$. Coraz częściej ulegają one swoistej „digitalizacji” wkomponowanej w struktury sieciowe o nie do końca jeszcze rozpoznanych i zmieniających się relacjach pomiędzy różnymi „rodzajami” rzeczywistości. Teza ta polemicznie odnosi się do twierdzeń Marka Postera, jednego z najwybitniejszych analityków wczesnych procesów wirtualizacji, który zakładał ich destrukcyjny wpływ na dotychczasowe formy istnienia tożsamości kulturowych ${ }^{4}$.

Świat łączący elementy realne, w znaczeniu klasycznego postrzegania rzeczywistości, i wirtualne, których z pewnością nie można nazwać „nierealnymi”, kształtowany jest przez świadomą działalność człowieka, mającą wymiar symboliczny, a zarazem głęboko angażującą wszystkie pokłady osobowości, emocji i wartości. Powstaje w ten sposób nowy rodzaj doświadczeń kulturowych wpisujący się w obszar istniejących, ale i powstających dopiero struktur społecznych, grup oraz ich symbolicznych reprezentacji, wśród których istnieją także transformujące się kultury narodowe o zupełnie nowej roli kultury symbolicznej, coraz bardziej poddanej procesom wirtualizacji. To one ze względu na postępujące procesy dywersyfikacji kulturowej, wywoływane procesami globalizacji, przemieszczeń i deterytorializacji wzorców kulturowych, narażone są najbardziej na synkretyzm nowych form rzeczywistości i transgresję swoich granic. Procesy te nie oznaczają ich zaniku, wręcz przeciwnie - prowadzą do zderzenia i nagromadzenia wielu kultur w tej samej przestrzeni interakcji. Zjawiska te powodują odkrywanie ich „wartości rdzennych", które wkomponowane były w głębokie struktury wspólnotowe i komunikacyjne. $Z$ drugiej strony wartości te nie mogą pozostać w istniejących do tej pory konfiguracjach wyznaczających stabilne wzory zależności, kanały przepływu i interakcji, muszą wejść w nowe obszary synergii, wzmacniane zupełnie nieznaną formą „systemowej inteligencji Internetu", nazywanej już czasami collective intelligence ${ }^{5}$. Procesy wirtualizacji są nowym instrumentem, ale i środowiskiem tej synergii nie bez znaczenia dla zaangażowanych w nie treści, sposobu ich odczytywania oraz miejsca w strukturze tożsamości. Medializacja kultury zrywa jednocześnie z zasadą liniowości, kumulatywności i planowości jej rozwoju zgodnie z istniejącymi do tej pory trendami.

Zmiany dokonujące się we współczesnym świecie stają się coraz bardziej gwałtowne i nieregularne, w dużym stopniu nieprzewidywalne, nie posiadają już tradycyjnych cech stopniowalności i ewolucyjności. Dzisiejszemu człowiekowi coraz trudniej żyć w otoczeniu procesów nieciąglych, cechujących się przerywalnością, chwilowością,

3 L. Macfadyen, Virtual Ethnicity: The New Digitization of Place, Body, Language, and Memory, „Electronic Magazine of Multicultural Education” 2006, Vol. 8, nr 1, [online] http://www.eastern. edu/publications/emme/2006spring/macfadyen.pdf, 3 III 2013.

4 M. Poster, What's the Matter with the Internet?, Minneapolis 2001, Electronic Mediations, 3; tenże, Information Please. Culture and Politics in the Age of Digital Machines, Durham 2006; tenże, The Second Media Age, Cambridge 1995.

5 P. Lévy, Collective Intelligence: A Civilisation, przeł. C. Bell, „Crossings: eJournal of Art and Technology” 2001, Vol. 1, nr 1, [online] http://crossings.tcd.ie/issues/1.1/Levy, 3 III 2013. 
tymczasowością, przejściowością i ulotnością. Przejście od zmian płynnych, ewolucyjnych, często przewidywalnych do burzliwych, nieobliczalnych to wymóg wciąż następujących zwrotów w myśleniu i działaniu. Wymaga to coraz większej elastyczności postaw, myślenia, a także różnego typu kompetencji, które stanowią bazę dokonywanych zmian. Kompetencje kulturowe, będące podstawą uczestniczenia w kulturze narodowej, ulegają w procesach wirtualizacji znacznym transformacjom, zmieniając się z odtwórcze, nastawionych na reprodukcję, a więc trwanie wzorów kulturowych w postaci ich stabilnych konfiguracji, na konfiguracyjne kompetencje synergetycznego uniwersum kultury masowej o znacznym poziomie zróżnicowania, eklektyzmu i płynności znaczeń. Wirtualizacja kultury pozbawia przy tym znaczenia kulturowe ich poczucia „esencjalności” na rzecz symbolicznego oznakowania, swoistej gry symbolicznej we wszechobecnych procesach dyskursu jako swoistej "gry" i sztuki komponowania doraźnych, często abstrakcyjnych i wymiennych znaczeń. Wirtualne symulakry znaczeń zastępują ich realne odniesienia, a gry emocjonalne zastępują autentyczne przeżywanie wartości. Znaczenia znaczeń wypierają fundamentalne struktury tożsamości wkomponowane w praktyki oznaczania, przekazu, kodowania, transtekstualności pozbawione rozpoznawalnych granic odniesienia. Kultury narodowe przestają być przedmiotem reprodukcji, stają w obliczu wszystkich wymienionych procesów, wśród których zmiana, konfigurowanie, rekompozycja i gry symboliczne przeistoczyły się w codzienną praktykę rzeczywistości wirtualnej.

Jednym z pierwszych, który pisał o problemach związanych z żegnaniem się z epoką ciągłości i stopniowych zmian, był Peter Drucker. Stawiał on wyraziście tę kwestię już w latach 60., gdy pisał, że jedyną stałą rzeczą w gospodarce jest zmiana, a najlepszym sposobem na przewidywanie przyszłości jest jej kształtowanie ${ }^{6}$. Gdy Drucker pisał o wchodzeniu w epokę nieciągłości, globalizacja była w fazie wstępnej, o Internecie wiedziało jeszcze niewielu akademików, a społeczeństwo informacyjne w Japonii, kraju, w którym po raz pierwszy użyto tego pojęcia w systematyczny i naukowy sposób, było we wstępnej fazie kształtowania. Rozszerzenie się przestrzeni funkcjonowania współczesnego człowieka o wymiar wirtualny, w którym zatracają się tradycyjnie rozumiane pojęcia czasu, miejsca, odległości i granic, jeszcze w większym stopniu, nawet w stosunku do druckerowskiego czasu nieciągłości, pogłębiło intensywność i jakościowy charakter współczesnych zmian.

Kumulacja zmian w infrastrukturze kulturowej społeczeństw współczesnych i towarzysząca im nieadekwatność wielu klasycznych kategorii opisu kulturowego przyspieszyła starzenie się, a w związku z tym konieczność przebudowy i modyfikacji rozumienia wielu idei, koncepcji i pojęć. Duża część doświadczeń i zdobytej w czasach względnej stabilności systemów wiedzy traci lub radykalnie przeobraża swoje znaczenie. Coraz trudniej jest też opisać, posługując się dotychczasowymi pojęciami, przemiany, których istotę intuicyjnie rozumiemy, ale brak nam zasobów definicyjnych i pojęciowych do oddania ich natury. Stąd też wiele pojęć, którymi posługujemy w sposób

$6 \quad$ P. Drucker, The Age of Discontinuity. Guidelines to Our Changing Society, New Brunswick 1992, s. 3-11; R. Kanter, Co powiedziatby Peter Drucker?, „Harvard Business Review Polska” XI 2009, s. 51. 
często rutynowy, wymaga redefinicji, ponownego określenia ich znaczenia w odniesieniu do współczesnych uwarunkowań.

Wśród wielu niezagospodarowanych w przestrzeni wirtualnej problemów na uwagę zasługuje zagadnienie obecności człowieka w wielokulturowym świecie bez granic, gdzie określenie pojęcia kultur narodowych wymaga nowego spojrzenia. Trudno tu mówić o „funkcjonowaniu” kultury w ścisłym uzależnieniu od konkretnego terytorium czy też w fizycznych jego granicach, w których bez wątpienia znajduje swoje miejsce wiele kultur i grup narodowych, etnicznych czy religijnych ${ }^{7}$. W nowej przestrzeni kulturowej i międzykulturowej człowieka, łączącej elementy realne i wirtualne, jak również ze względu na narastającą mobilność wielu elementów, a nawet subsystemów poszczególnych kultur, w tym nie tylko narodowych, coraz większego znaczenia nabiera bliskość i relacja wartości, szczególnie wartości rdzennych, odczytywanie i rozumienie dziedzictwa, projektowanie sposobów interakcji, rozpoznawanie strategii rozwojowych w warunkach cywilizacji medialnej, a mniejsze znaczenie mają rytuały symboliczne i ich powiązanie z terytorialnymi wyznacznikami klasycznie pojmowanego miejsca ${ }^{8}$.

\section{OD GALAKTYKI GUTENBERGA DO GALAKTYKI INTERNETU9}

Ludzie, jak długo są bytami, nie mogą żyć i działać inaczej niż w przestrzeni. Odkąd pojawiła się przestrzeń wirtualna, będąca nowym symbolicznym terytorium obecności człowieka, wspomniany byt staje się także elementem kultury symbolicznej, która nabiera cech własnej realności, nieznanej w dotychczasowej historii kultury i cywilizacji. Bez względu na jej naturę tworzone przestrzenie odzwierciedlają i kształtują życie społeczne w nowej, właściwej sobie formie ${ }^{10}$.

Przyjęta teoria przestrzeni ujmująca ją jako relacje społeczne, współcześnie głoszona przez Manuela Castellsa, wywodzi się od Gottfrieda Wilhelma Leibniza. Twierdził on, że przestrzeń tworzy się pomiędzy rzeczami, zatem niemożliwa jest przestrzeń pusta. To obiekty tworzą przestrzeń, jest ona formułowana przez istniejącą między nimi relację. Bez obiektów nie ma nic między nimi, zatem nie ma przestrzeni ${ }^{11}$. Koncepcja

N. Zurawski, Ethnicity and the Internet in a Global Society, 1996, [online] http://www.isoc.org/ inet96/proceedings/e8/e8_1.htm, 14 III 2013.

8 L. Korporowicz, Socjologia kulturowa. Kontynuacje iposzukiwania, Kraków 2011; tenże, Polimorficzna przestrzeń tożsamości, „Politeja” 2012, nr 20/2: Wspótczesna przestrzeń tożsamości.

9 Pojęcie „galaktyka Gutenberga” wprowadził w latach 60. Marshall McLuhan, umieszczając je w tytule swojej pracy Galaktyka Gutenberga, z kolei pojęcie „galaktyka Internetu” zostało użyte po raz pierwszy na początku tego stulecia przez Manuela Castellsa, który nawiązując do dzieła Marshalla McLuhana, również umieścił je w tytule swojej książki: Galaktyka Internetu. Refleksje nad Internetem, biznesem ispoteczeństwem.

10 Według Castellsa nie istnieje, nawet implicite, teoria przestrzeni niebędąca integralną częścią ogólnej teorii spotecznej - M. Castells, Kwestia miejska, przeł. B Jałowiecki, J. Piątkowski, Warszawa 1982, s. 123.

11 Argumenty Gottfrieda W. Leibniza i Isaaca Newtona były natury teologicznej. Z jednej strony głosili oni, iż przestrzeń tworzą rzeczy stworzone przez Boga, z drugiej zaś, że przestrzeń nie może być absolutna, ponieważ Bóg zawsze może interweniować w jej naturę. 
Leibniza odnosiła się do przestrzeni relacyjnej, skończonej i elastycznej. W przeciwieństwie do tego ujęcia Isaak Newton pojmował przestrzeń jako byt absolutny, zakładając, że istnienie rzeczy jest poprzedzane istnieniem przestrzeni. Obiekty są umieszczone w nieskończonej i niezmiennej przestrzeni, która nie jest z nimi związana.

Spór Leibniza i Newtona rozgrywał się w czasie głębokich przeobrażeń społeczeństwa europejskiego, gdy Europa wkraczała w „galaktykę Gutenberga”. Okres gwałtownych zmian, wywołanych rozwojem technologii druku, postawił społeczeństwo na pograniczu dwóch kultur i przeciwstawnych technik. Ukształtowane tym samym zostały dwa przeciwstawne modele społeczne: jeden oparty na piśmienności, drugi na oralności. Nowa kultura piśmienności usuwała dialog, interaktywność i współdziałanie w cień, wprowadzając podział na autora i czytelnika, nadawcę i odbiorcę.

Dziś jesteśmy świadkami podobnie głębokich przeobrażeń przestrzeni kreowanej obecnie przez coraz szybszy rozwój technologii informatyczno-komunikacyjnych, rozwijających nowy obszar obecności człowieka - „galaktykę Internetu” ${ }^{12}$. Nie jest to cykliczny powrót do dawnych koncepcji, jak niekiedy wydaje się sugerować Marshall McLuhan. Trafniejsze wydaje się określenie Waltera Onga, który to odrodzenie nazywa „wtórną oralnością" ${ }^{13}$ komunikacji elektronicznej, choć określenie to koniecznie należy uzupełnić rosnącym w społeczeństwie informacyjnym znaczeniem wizualności przekazu, który zyskuje wiele własnych i wyspecjalizowanych analiz. Dominujący obecnie informacyjny sposób komunikacji nadaje nowe znaczenie sposobom konceptualizacji świata. Współczesna przestrzeń wirtualna wpisuje się w Newtonowską wizję nieskończoności, tym samym rekonceptualizując dotychczasową ideę przestrzeni. Przywrócona zostaje dawna koncepcja przestrzeni charakteryzującej się ciągłością, niezależnością od tego, co w sobie zawiera, a jednocześnie odznaczającej się nieskończoną podzielnością, jak również nieskończoną rozciągłością. Nowa przestrzeń jest w równej mierze wytworem współczesnej cywilizacji technicznej, bez której wirtualizacja nie byłaby w ogóle możliwa, jak i źródłem generowanej przez nią dynamiki społecznej. Sama rzeczywistość społeczno-kulturowa postrzegana jest, co podkreślał w swoich analizach McLuhan, poprzez pryzmat zmian zachodzących w technologii, które pociągają za sobą głębokie przeobrażenia kulturowe ${ }^{14}$. Współczesny człowiek opuścił galaktykę Gutenberga, by wylądować w globalnej wiosce, symbolizującej zamkniętą wspólnotę, w której nikt nie jest anonimowy, gdzie informacja rozchodzi się błyskawicznie i w której większe znaczenie ma komunikacja niż refleksja ${ }^{15}$. Jednocześnie w przestrzeni tej człowiek nie ma bezpośredniego dostępu do rzeczywistości, uczestniczy w niej, a zarazem kreuje ją tylko w sposób pośredni, przekształcając dane w obiekty pracy umysłu. Pomiędzy umysłem

12 M. Castells, Galaktyka Internetu. Refleksje nad Internetem, biznesem i spoteczeństwem, przeł. T. Hornowski, Poznań 2003, Nowe Horyzonty.

13 „Wtórna oralność”, ponieważ oralność telefonów, radia czy telewizji jest efektem istnienia pisma i druku. W. Ong, Oralność i piśmienność. Stowo poddane technologii, przeł. J. Japola, Lublin 1992, s. 3.

14 F. Mihir, Virtual Ethnicity: A Study on Ethnicity \& Technology Usage, „Proceedings of Society for Information Technology and Teacher Education International Conference" 2009, Vol. 40, nr 4.

15 E. Bendyk, E-learning, zerwanie z tradycja humanizmu?, „E-mentor” 2009, nr 1, [online] http:// www.e-mentor.edu.pl/artykul/index/numer/28/id/606, 3 III 2013. 
a rzeczywistością rozpościera się jednak nieredukowalna różnica ${ }^{16}$. Gregory Bateson nazwał tę różnicę informacją. Przy czym informacja przekazywana z wykorzystaniem technologii również wpływa na postrzeganie świata - zarówno tego wirtualnego, jak i realnego, od konstrukcji oprogramowania hipertekstu zależy bowiem, do jakich informacji dotrze mieszkaniec galaktyki Internetu.

Coraz większa obecność mediów elektronicznych i pomniejszająca się rola mediów tradycyjnych spowodowała przemianę współczesnego świata, coraz wyraźniej dzieląc go na dwie przestrzenie: realną i wirtualną, chociaż obserwując rosnącą rolę zastosowań wirtualnych, mówić należy o rosnącej synergii obu tych realności, a nawet ich relatywności ze względu na obecność elementów symbolicznych i konceptualnych w rzeczywistości realnej i „nową realność” doświadczenia wirtualnego, które wymaga jednak realności człowieka. Wciąż otwartą kwestią jest wpływ i zależność tych dwóch światów.

Jak zauważa Tomasz Goban-Klas, pomimo iż rzeczywistość wirtualna jest jeszcze iluzją, to wpływ, jaki Internet wywiera na charakter relacji międzyludzkich, jest faktem ${ }^{17}$. Tym samym współczesna przestrzeń obecności człowieka dzięki rozwojowi technologii informacyjno-komunikacyjnej została poszerzona o nowy wymiar - przestrzeń wirtualną. Derrick de Kerckhove określa ją jako stan poznania, który tworzy trzecią przestrzeń, wykraczając poza pierwszą - przestrzeń fizyczną, i drugą - przestrzeń mentalną (zawartą w umyśle) ${ }^{18}$. Uczeń McLuhana podkreśla jej technologiczny i elektroniczny charakter, jednocześnie wskazując na jakościową odmienność przejawiającą się w niematerialnej, immersyjnej, kognitywnej i zintegrowanej naturze.

Wykraczając poza wszystkie wymienione wyżej cechy, należy podkreślić, iż efektem dzisiejszej rozbudowy przestrzeni obecności człowieka stało się doświadczanie „od-dalenia" ${ }^{19}$ od świata tradycyjnego kształtowanego przez świadomą działalność, mającą wymiar symboliczny, a zarazem wyznaczaną stanami emocjonalnymi, uczuciowymi, silnie wartościującymi, adaptującymi przestrzeń do własnych wyobrażeń, przy jednoczesnym jej doświadczaniu. Nowa przestrzeń stała się osobliwym rodzajem socjotechnicznego fenomenu, zmiennego, nieprzewidywalnego i bezładnego. Jej niezwykłość należałoby również rozpatrywać w aspekcie jej pozawymiarowości, przekraczającej jedyne dotychczas nam znane wymiary fizyczne.

Najgłębiej tkwiące w człowieku przekonanie, mające również charakter intuicyjny, mówi, że żyjemy w trójwymiarowym świecie, tzn. wszystko da się opisać, posługując się trzema wymiarami: szerokością, długością i głębokością. Nieżyjący już fizyk Heinz Pagels zauważył to przywiązanie, pisząc: Jedna z cech naszego fizycznego świata wyda-

16 W nawiązaniu do tezy postawionej przez Alfreda Korzybskiego - „mapa nie jest terytorium”.

17 T. Goban-Klas, Ontologia Internetu, [w:] Spoteczeństwo informacyjne. Wizja czy rzeczywistość? II ogólnopolska konferencja naukowa, t. 1, red. L.H. Haber, Kraków 2004, s. 39.

18 D. de Kerckhove, Przeciw architekturze (architektura inteligencji), [w:] Kody McLuhana. Topografia nowych mediów, red. A. Maj, M. Derdy-Nowakowski, Katowice 2009, s. 38, Medioznawstwo.

19 O efekcie „od-dalenia” świata wywołanym pojawieniem się radia pisał w Byciu $i$ czasie Martin Heidegger, przypisując temu medium możliwość transformacji przestrzenności oraz czynienia świata dostępnym i osiągalnym dla wszystkich. M. Heidegger, Bycie i czas, przeł. B. Baran, Warszawa 2004, s. 135, Biblioteka Wspótczesnych Filozofów. 
je się tak oczywista, że większość ludzi przyjmuje ja bez zdziwienia - trójwymiarowość przestrzeni ${ }^{20}$. Einstein rozszerzył to pojęcie, włączając czas jako czwarty wymiar, ale współcześni uczeni chcą wyjść poza wprowadzoną przez niego koncepcję czwartego wymiaru, a ich zainteresowania ogniskują się wokół wymiarów wyższych. Temat istnienia hiperprzestrzeni jest coraz częściej podejmowany przez współczesnych fizyków. Obecnie duże uznanie zyskuje teoria hiperprzestrzeni Kaluzy-Kleina czy teoria superstrun określająca dziesięć wymiarów przestrzeni i czasu, co ukazuje, jak bardzo można poszerzyć nasze stereotypowe myślenie nie tylko o tzw. cyberprzestrzeni, lecz także o jej wariantach w realiach współczesnej cywilizacji i kultury.

Aby w pełni zrozumieć istotę obecności człowieka w przestrzeni wirtualnej, należałoby ją przenieść do nowego, piątego wymiaru ${ }^{21}$. Z jednej strony rozwój nowych technologii podważyłby głęboko zakorzenione wyobrażenie o trzech (czterech, jeśli dodamy czas) wymiarach świata, po raz pierwszy dyskutowane przez starożytnych filozofów greckich dwa tysiące lat temu, ale $\mathrm{z}$ drugiej strony zabieg ten umożliwiłby interpretację wielu procesów zachodzących w Internecie. Już dzisiaj wśród naukowców rośnie świadomość, że każda czterowymiarowa teoria jest „zbyt ciasna”, aby opisać zjawiska pojawiające się we współczesnym świecie. Przykładem tego ograniczenia jest działanie na podstawie głęboko zakorzenionego przekonania, że świat jest sekwencją prostych połączeń, tzn. określone drzwi zawsze prowadzą do znanego już miejsca, które jest niezmienne, a na pewno przewidywalne. Łatwość zmiany świata za drzwiami w świecie wirtualnym jest imponująca. Wchodząc na konkretną stronę internetową, nigdy nie oczekujemy widoku z poprzedniego dnia, przeciwnie - oczekujemy zmiany. Twórcy stron starają się je na bieżąco modyfikować, wymyślać nowe formy, które przyciągną uwagę. Nigdy też nie mamy pewności, czy strona ta nadal istnieje albo czy nikt inny nie zagospodarował tego obszaru.

W rozważaniach nad nowym modelem obecności człowieka interesujące może być zagadnienie, czy istnieje połączenie między światem realnym i wirtualnym, a także w jakim zakresie i formie można przenosić się z jednego do drugiego. To przemieszczanie się między światami równoległymi ${ }^{22}$ przypomina model tuneli, które pozwalają na przenoszenie w inny obszar przestrzeni i czasu. Światy równoległe, które można porównać do dwóch równoległych płaszczyzn, nie są ze sobą w żaden sposób powiązane, dopóki nie zostanie utworzony pomiędzy nimi tunel, umożliwiający komunikację i podróże. Wielokrotność połączeń między światem wirtualnym a realnym polega na tym, iż podróże z jednego do drugiego można odbywać w dowolnym czasie i dowolnie często. Nawet jeśli bycie w Internecie wiąże się tylko z bytem mentalnym.

20 H. Pagels, Perfect Symmetry. The Search for the Beginning of Time, New York 1985, s. 324.

21 S. Jaskuła, Piaty wymiar w edukacji międzykulturowej, [w:] Poza paradygmaty. Pedagogika międzykulturowa. Księga pamiątkowa dedykowana profesorowi Tadeuszowi Lewowickiemu, t. 2, red. A. Szczurek-Boruta, E. Ogrodzka-Mazur, Torun 2012.

22 Świat realny i wirtualny można określić mianem „światy równoległe”; życie w jednym i drugim toczy się niezależnie, człowiek może w nich funkcjonować zamiennie, oczywiście w jednym z nich tylko w wymiarze metaforycznym. 
Powstanie przestrzeni wirtualnej budzi dzisiaj coraz więcej pytań o relacje, współistnienie, powiązania, odniesienia, przeniesienia, ale i różnice w stosunku do tradycyjnej przestrzeni, określanej w literaturze jako realna, czyli ta, której jednym z wyznaczników jest jej wymiar fizyczny. Nie mniej fascynująca jest umiejętność współczesnego człowieka poruszania się, istnienia, ale i funkcjonowania czy też współtworzenia jednocześnie w obu tych światach, które są tak samo odlegle, jak i bliskie. Człowiek, od tysięcy lat przystosowujący się do życia na Ziemi, w ciągu zaledwie kilku nauczył się żyć w przestrzeni wirtualnej, którą dostosowuje do ujarzmionej już i poznanej przestrzeni realnej, a jednocześnie przenosi w tę projektowaną sferę znane mu z przeszłości formy istnienia, cały bagaż minionych doświadczeń, zarówno tych uświadomionych, jak i tych nieświadomych.

Giddensowska „epoka oszałamiającej zmiany” ma swój najwierniejszy i jednocześnie mobilny obraz w nowym wirtualnym świecie tworzonym przez człowieka w sieci. Ten nowy obszar aktywności ludzkiej wyznacza nowe formy przestrzeni, dla których trudno znaleźć określenia, wymykają się one bowiem opisowi w kategoriach fizycznej odległości jej nośników. Przestrzenie te stają się coraz bardziej złożoną całością interakcji, spotkań, zyskują coraz więcej wartości i funkcji łączących światy realne i wirtualne, indywidualne i społeczne, przeszłe i projektowane. Ich zrozumienie wymaga bardzo różnych koncepcji realności wypracowanych na gruncie wielu dyscyplin i metodologii. Tak samo trudne jest samo ich zdefiniowanie, bowiem terminy, którymi się posługujemy, zostały ukształtowane w warunkach, które już nie istnieją, a używanie ich w stosunku do przestrzeni, w której się dzisiaj poruszamy, może mieć charakter jedynie metaforyczny. Nowe przestrzenie - powstające w interakcji i przy oddziaływaniu wielu podmiotów, stające się częścią dynamicznych, często w istotny sposób „odcieleśnionych" procesów komunikacji - łączą zatem zarówno elementy klasyczne, jak i metafizyczne czy symboliczne. Bez względu na to, czy współczesna przestrzeń (współczesne przestrzenie) Internetu to jeszcze struktura pierwotnych oddziaływań czy już rozwinięta cywilizacja, rodzi ona już dzisiaj możliwości skorzystania z wielu nowych szans, ale może być też miejscem powstawania nowych zagrożeń, a nawet patologii.

Zrozumienie zachodzących w przestrzeni wirtualnej przemian kulturowych i społecznych możliwe jest jedynie wówczas, gdy rozważymy działanie mediów jako środowiska ${ }^{23}$. Współczesna przestrzeń obecności człowieka, rozszerzona o wymiar wygenerowany przez Internet, przedłużyła również nasze zmysły, powodując tym samym zmianę w naszym sposobie postrzegania świata, a także zmianę sposobu myślenia i działania. Przy czym na zmianę człowieka i postrzegania przez niego świata wpływ mają nie tyle konkretne przekazy, ile ogół właściwości nowych mediów, będących producentami złożonych przekazów, rekonstruowanych przez ich audytoria i użytkowników jako struktury znaczące.

Oczywiste jest, że istnienie przestrzeni wirtualnej nie jest możliwe bez istnienia przestrzeni realnej (implikacja jednostronna), przecież to realni ludzie ją budują, bez

23 M. McLuhan, Q. Fiore, War and Peace in the Global Village. An Inventory of Some of the Current Spastic Situations that Could Be Eliminated by More Feedforward, New York 1968, s. 41. 
względu na to, jakie stworzą w niej obrazy siebie i jakie funkcje i role sobie w niej przypiszą. Jednokierunkowość tej implikacji nie jest jednak taka jednoznaczna i oczywista. Tak samo trudny do określenia jest rodzaj wpływu bądź symbiozy tych dwu przestrzeni, która może być interpretowana jako:

- forma współistnienia o obustronnych korzyściach, która praktycznie wzajemnie uzależnia od siebie obie przestrzenie (mutualizm);

- stosunek między strukturami, z których jedna funkcjonuje jako niewolnik drugiej (helotyzm);

- współegzystencja korzystna dla jednego z partnerów, dla drugiego zaś obojętna (komensalizm);

- czy wreszcie forma koegzystencji dwóch struktur, w której jedna czerpie korzyści ze współistnienia, a druga ponosi szkody (parazytyzm) ${ }^{24}$.

Jednak bez względu na rodzaj współzależności powstaje nowa, synergetyczna przestrzeń, w której spotykają się, tworząc nową, „trzecią jakość, dwa jej aspekty - realny i wirtualny, kształtując tym samym nowa eksterytorialnąprzestrzeń spoteczną ${ }^{25}$. Generuje ona nowy, realno-wirtualny świat, w którym człowiek już nie tylko przebywa, ale może też na niego aktywnie oddziaływać, a nawet więcej - konstruować zgodnie ze swoimi potrzebami i marzeniami. Łatwość budowania świata fantazji wynika z faktu „odfizycznienia” jego elementów oraz braku ograniczeń jego uczestników do formy fizycznej obecności w wyznaczonych i stabilnych granicach. We współczesnym wirtualnym świecie obecność człowieka jest zapośredniczona (teleobecność), człowiek sprzęgnięty jest z nim poprzez mechaniczne urządzenia. Przy czym teleobecność nie tylko jest związana z rzeczywistością wirtualną, lecz odzwierciedla także uruchamianie dwóch perspektyw. Pierwsza z tych perspektyw zanurza człowieka w świecie w znacznym stopniu fikcyjnym, druga wprowadza nieusuwalny dystans w stosunku do powyższego świata, człowiek może w nim bowiem uczestniczyć tylko poprzez użycie urządzeń elektronicznych. Teleobecność to bycie w dwóch wymiarach jednocześnie - uczucie bycia w obu, ale wytwarzające się z doświadczenia bycia w rzeczywistości realnej ${ }^{26}$.

Jedna z podstawowych różnic pomiędzy przestrzenią realną a wirtualną dotyczy priorytetowej kategorii fizycznej związanej z określaniem w ścisły, parametryczny sposób położenia ${ }^{27}$. W nowej przestrzeni obecności człowieka, w odróżnieniu od przestrzeni tradycyjnej, pojęcie miejsca traci na znaczeniu, brak tu klasycznych odniesień fizycznego istnienia, bytu. Nic, co się tu znajduje, nie jest powiązane z żadnym konkretnym parametrem miejsca, co więcej - zanika potrzeba identyfikacji fizycznego po-

24 S. Jaskuła, Symbioza i odrębność dwóch światów, „Politeja” 2012, nr 20/2: Wspótczesna przestrzeń tożsamości. Terminy „mutualizm”, „helotyzm”, „komensalizm” i „parazytyzm”, zasięgnięte z biologii, odnoszą się do interakcji protekcjonistycznych między populacjami.

25 Termin zaproponowany przez Zygmunta Baumana w: tenże, Ptynne życie, przeł. T. Kunz, Kraków 2007.

26 S. Jaskuła, Общества в новом информационном пространстве, „Міжнародний науковий форум: соціологія, психологія, педагогіка, менеджмент" 2010, $\mathrm{nr} 2$.

27 Taż, New Forms of Mobility in the Word of Virtualization and Medialization of Cultures, „Politeja” 2012, nr 20/1: Mobility of Cultures. 
łożenia, którego i tak nie sposób ustalić. Jednocześnie przebywanie w dwóch lub więcej miejscach w tym samym czasie jest czymś niezwykłym. Traci tu również na znaczeniu pojęcie $c z a s u$, dostęp do elementów przestrzeni wirtualnej możliwy jest bowiem poza jednoznacznie określonym czasem, a odniesienia czasowe można powielać, przesuwać i czynić jedynie parametrem sytuacji. Ta nieistotność czasu w przestrzeni wirtualnej jest całkowicie odmienna od znaczenia czasu w przestrzeni klasycznej, gdzie całe działanie człowieka podporządkowane jest wyznaczonemu i zakresowo określonemu terminowi.

W przestrzeni wirtualnej obowiązuje zasada eksterytorialności, granice „nowego terytorium” są niezależne od przestrzeni fizycznej, materialnej, przyrodniczej, w których osadzony jest człowiek podczas swojej codziennej egzystencji. Świat wirtualny jest potężnym narzędziem uniezależniania się od lokalnych, kontekstualnych i fizycznych ograniczeń, systematycznie powiększa się tu możliwość przenoszenia z jednego miejsca $\mathrm{w}$ inne lub w wiele miejsc jednocześnie. Zmienia się w związku z tym również sama aktywność człowieka, stając się mobilną, przestrzennie rozproszoną, często trudną do lokalizacji lub dziejącą się w wielu miejscach jednocześnie. Cyberprzestrzeń jest przestrzenią ruchu, a ludzie w niej przebywający zamieszkują w swoistych „pejzażach ruchu” $\mathrm{i}$ „tunelach podróży” ${ }^{28}$ (tu, za chwilę gdzie indziej). W przestrzeni wirtualnej zupełnie nowego znaczenia nabiera pojęcie stałości, bycie w niej bowiem nie jest niczym innym jak ciągłym przemieszczaniem i poruszaniem się w niej, tym samym przestrzeń wirtualna wypiera niezwykle złożoną różnorodność preegzystujacej przestrzeni fizycznej ${ }^{29}$. Samo poznawanie przestrzeni wirtualnej, które, przynajmniej w obecnym stadium jej rozwoju, nie jest poznawaniem historycznym, wykazuje się istotną niesymetrycznością. Nastąpiła wyraźna zmiana kierunków poznawczych: nie ludzie wychodzą do świata, żeby go poznać, a świat przychodzi do nich. Obraz świata jest transportowany bezpośrednio w symboliczną przestrzeń, w której człowiek doświadcza jakby swoistego paraliżu, pozostając wobec niego w bezruchu ${ }^{30}$. Bezruch ten dotyczy tylko sfery fizycznej i odnosi się do świata realnego, w stosunku do świata wirtualnego bowiem człowiek w tym samym czasie wykazuje się dużą aktywnością pozafizyczną, w tym np. mentalną. Co więcej, człowiek jest zanurzony w tym świecie, nawet gdy nie jest aktywny. Przebywanie poza jego progami nie oznacza zamierania w nim aktywności danej jednostki (na jej konta wciąż przychodzą e-maile, uaktywniają się skrypty, które w jej imieniu wygenerują automatycznie odpowiedź nadawcy, na forach dyskusyjnych komentowane są wypowiedzi jednostki itp. $)^{31}$.

28 J. Urry, Socjologia mobilności, przeł. J. Stawiński, Warszawa 2009, s. 109, Socjologia Wspótczesna.

29 M. Heim, The Erotic Ontology of Cyberspace, [w:] Cyberspace. First Steps, red. M. Benedikt, Cambridge (Mass.) 1991, s. 74.

30 K. Pankowska, Rzeczywistość zapośredniczona - nowe problemy wzrastania dziecka $w$ przestrzeni medialnej, [w:] Media elektroniczne - kreujące obraz rodziny i dziecka, red. J. Izdebska, Białystok 2008, s. 16.

31 S. Jaskuła, Intercultural Space. Contemporary Challenges and Perspectives, [w:] Poland - Jordan European Union: Future Aspects. Conference, December 15, 2010, red. S. Abudayeh, K. Bojko, Amman 2011. 
Dzisiejsza przestrzeń człowieka, łacząc wymiary realne i wirtualne, nie tylko pokazuje rzeczywistość, ale też kreuje ją na niespotykaną dotąd skalę, aż do pełnej symulacji, oderwania się od rzeczywistosci, o czym mówi słynna teoria symulakrów, gdzie „symulakrum" to kopia mająca maksimum rysów oryginału, lecz bez jej faktycznych cech. Symulakrum „udaje” obecność tego, czego nie ma, wprowadza dezorientację, przywołuje wrażenie realności, podczas gdy stanowi jedynie kopię czy iluzję. Kopie symulakrum nie odnoszą się już do rzeczywistości, lecz tylko i wyłącznie do nich samych, a granice pomiędzy fikcją a rzeczywistościa ulegają zatarciü ${ }^{32}$. Tworzona przestrzeń, z założenia jakościowo lepsza, piękniejsza i doskonalsza, czyni symulakrę coraz doskonalszą.

Kultury narodowe są w samym centrum procesów łączenia rzeczywistości realnej i wirtualnej, absorbując niemal wszystkie konsekwencje ich spotkania według wymienionej wcześniej typologii. Przekraczanie granic i zapośredniczenie procesów komunikacji osłabiają siłę więzi i rozmywają identyfikację wartości rdzennych, ale z drugiej strony poszerzają przestrzeń komunikacji w diasporach, wkomponowują się w kanały mobilności kulturowej i wspomagają pokonywanie wewnętrznych podziałów społecznych.

\section{SPOŁECZNOŚCI WE WSPÓŁCZESNEJ PRZESTRZENI WIRTUALNEJ}

Zdumiewająca dynamika współczesnych mediów, nie tylko formułująca, ale również w bardzo szybkim tempie modyfikująca nową przestrzeń obecności człowieka, tworzy tym samym nowe formy społeczno-kulturowe. Dyskusja nad społecznymi wymiarami Internetu rozpoczęła się już w latach 90. Podstawowe pytanie dotyczyły tego, na ile i czy w ogóle Internet wspiera rozwój wspólnot, czy wręcz przeciwnie - prowadzi do izolacji, rozrywając więzi łączące ludzi ze społeczeństwem. Tezę o powstawaniu nowych form wspólnot, skupiających online ludzi wokół wspólnych zainteresowań i wartości oraz mogących się w ten sposób rozwijać, przedstawił wówczas Howard Rheingold w pionierskiej wówczas książce Virtual Communitiy ${ }^{33}$. Stanowisko to poparł William Mitchell, dowodząc, że w przestrzeni wirtualnej pojawiają się nowe formy uspołecznienia i nowe formy życia miejskiego, przystosowane do nowego środowiska budowanego z wykorzystaniem technologii informacyjno-komunikacyjnych ${ }^{34}$. Na odmienność tych form wspólnotowych wskazała w jednym z pierwszych psychoanalitycznych studiów poświęconym użytkownikom Internetu Sherry Turkle, akcentując możliwości tworzenia poczucia wspólnoty, ale często o charakterze efemerycznym i przebiegającym w równoległym życiu, choć podyktowanym potrzebami fizycznej jaźni. Wirtualne wspólnoty oferują radykalnie nowy kontekst myślenia o tożsamości ludzkiej w wieku Internetu ${ }^{35}$.

32 J. Baudrillard, Precesja symulakrów, [w:] Postmodernizm. Antologia przektadów, red. R. Nycz, Kraków 1998.

33 H. Rheingold, The Virtual Community. Homesteading on the Electronic Frontier, Reading 1993.

34 W. Mitchell, City of Bits. Space, Place and the Infobahn, Cambridge (Mass.) 1995; tenże, E-topia. "Urban Life, Jim - But Not as We Know It", Cambridge (Mass.) 1999.

35 S. Turkle, Life on the Screen. Identity in the Age of the Internet, New York 1995, s. 267. 
W tym samym czasie przeciwstawną ocenę zjawiska w postaci krytyki nowych form życia społecznego tworzonych poprzez narastającą komputeryzację wyraził Mark Slouka, który wskazał na liczne formy dehumanizacji powstających za ich pośrednictwem relacji społecznych i nowych form mentalności. Współczesne destrukcje, a wręcz patologie w perspektywie badań społeczeństwa informacyjnego analitycznie przedstawia Brunon Hołyst, wskazując na implikacje w sferze ładu społecznego i wielorakich ubocznych konsekwencji nie tyle rozwoju, co wzrostu cywilizacyjnego ${ }^{36}$.

Procesy te mają niewątpliwie swoje makrostrukturalne ramy, które sprawiają, iż dzieją się one niejako niezależnie od naszej woli, postaw czy stosunku do sposobu ich istnienia. Są to:

- narastająca mobilność: towarów, usług, technologii, informacji i ludzi;

- deterytorializacja;

- multiplikacja informacji;

- konwergencje i interakcje społeczne;

- poszerzanie i „eksplozja” przestrzeni informacyjnej i kulturowej;

- metamorfozy struktur i ładu społecznego.

W tych to właśnie ramach tworzą się nowe instytucje, powstają nowe role, formy i systemy komunikowania, które same w sobie są nową formą rzeczywistości. Nie towarzyszą jej w charakterze społecznego artefaktu, ale fakty te stwarzają, są realnością ludzkich interakcji, doświadczeń i wyobrażeń zarówno na poziomie relacji społecznych, jak i w tym, co Manuel Castells nazywa w swojej książce pod znamiennym tytułem Wtadza komunikacji - kultura usieciowionego indywidualizmu ${ }^{37}$.

Niezależnie od krytyki, jaką można skierować pod adresem nowych form uspołeczniania, stwarzanych przez społeczeństwo informacyjne, medialna przestrzeń obecności człowieka, charakteryzująca się ogromnym stopniem innowacyjności, pokazuje wyraźnie, jak bardzo dynamiczne i różnorodne są procesy jej społecznej aplikacji. Mnogość interakcji i relacji społecznych zmieniających się w różnych kontekstach, jakie wytwarza przestrzeń wirtualna, powoduje generowanie odmiennych typów społeczności dostosowywanych do różnych sytuacji, co z jednej strony może wskazywać na ich wieloaspektowość i wielopoziomowość, ale z drugiej może być objawem silnego kryzysu społeczności. Stałe przekraczanie granic, ruchliwość, a często krótkotrwałość i „migotliwość” kontaktów międzyludzkich, stanowiące zasadniczą cechę nowoczesności, prowadzą do częstych zmian wizerunku uczestników przestrzeni. Wraz z przekształcaniem symbolicznej wizji świata i systemu relacji tożsamość staje się przedmiotem przekształceń zarówno w wymiarze jednostkowym, jak i grupowym. Owa tożsamość „projektująca” ${ }^{38}$ jest wynikiem różnego rodzaju strategii mieszania, a z drugiej strony łączenia się i budowy światopoglądów, postaw i wartości oraz intensywności zjawisk ścierania się i nakła-

36 B. Hołyst, Zagrożenia tadu spotecznego, t. 1, Warszawa 2013.

37 M. Castells, Wtadza komunikacji, przeł. J. Jedliński, P. Tomanek, Warszawa 2013, s. 133.

38 Castells w swojej książce Sita tożsamości wprowadza trzy typy tożsamości kulturowej w warunkach ponowoczesności: tożsamość legitymizującą, tożsamość oporu i tożsamość projektującą. Por.: M. Castells, Spoteczeństwo sieci, przeł. M. Marody i in., Warszawa 2007, Wiek informacji, t. 1; D. Barney, Spoteczeństwo sieci, przel. M. Fronia, Warszawa 2008, Key Concepts. 
dania kultur. Stanowi ona tym samym odpowiedź na dynamikę rozwoju współczesnego świata i wymogi procesów globalizacji, które żądają wyborów i samookreślenia.

Nie należy pomijać faktu, iż współczesna przestrzeń obecności człowieka daje szerokie możliwości zapośredniczenia doświadczeń, które z kolei kształtują tożsamość jednostki. W takich warunkach tożsamość jednostki staje się przedsięwzięciem refleksyjnym $^{39}$. Wspomniana refleksyjność, przejawiająca się w projektowaniu własnego ,ja”, odwołuje się do wielokrotnych wyborów związanych z współoddziaływaniem różnych grup społecznych. Z jednej strony utrzymywane są istniejące wybory tożsamościowe czy odwołania biograficzne, a z drugiej są one na bieżąco weryfikowane i modyfikowane. To nowe poczucie własnej tożsamości tworzy się w ramach procesu powstawania niespotykanych dotąd relacji społecznych. Nie należy przy tym pomijać ważnego faktu, iż doświadczanie samego siebie i własnych emocji w nowej przestrzeni informacyjnej odbywa się często w warunkach opuszczenia i osamotnienia, bez poczucia wsparcia psychicznego i bezpieczeństwa, odczuwanie wspólnotowości i tradycji jest bowiem zastępowane bezosobową grą projektów i wizerunków.

Autorzy prac badawczych poświęconych społeczeństwu informacyjnemu często wskazują na negatywne cechy atomizacji procesów socjalizacyjnych społeczeństwa wirtualnego ${ }^{40}$. Zwracają oni uwagę m.in. na brak zhierarchizowanej struktury społeczności wirtualnej, na niestabilność i ograniczoność ich struktury i celu funkcjonowania. Podkreślają, iż przynależność do społeczności wirtualnych jest słaba i podlega fluktuacji, a kultura i tożsamość konstruowana w Internecie jest ograniczona i wyklucza poważny dialog pomiędzy uczestnikami. Procesy te w szczególny sposób odnoszą się do kultur narodowych z racji faktu, iż to one właśnie wymagają nie tyle indywidualizacji, ile wspólnotowego charakteru procesów nazywanych przez Antoninę Kłoskowską kulturalizacja.

W'sód przykładów pejoratywnych cech społeczeństw wirtualnych najczęściej wymienia się:

- brak tradycyjnych regul funkcjonowania;

- nieobowiązywanie zasady więzi terytorialnych;

- brak wyznaczonych ról społecznych;

- brak hierarchii;

- płynność związków między społecznością a jednostką (łatwość porzucania społeczności wirtualnej przez jednostkę);

- język ograniczający relacje między wspólnotami;

- brak kontroli formalnych;

- wolność ograniczoną jedynie dostępem do technologii;

- niestabilność, brak mechanizmów zatrzymujących procesy fluktuacji i rozpadu;

39 A. Giddens, Nowoczesność i tożsamość. "Ja” i spoteczeństwo w epoce późnej nowoczesności, przeł. A. Szulżycka, Warszawa 2007, Biblioteka Socjologiczna.

40 CyberSociety 2.0. Revisiting Computer-Mediated Communication and Community, red. S.G. Jones, Thousand Oaks 1998, New Media Cultures, 2; J. Fernback, B. Thompson, Computer-Mediated Communication and American Collectivity. The Dimensions of Community Within Cyberspace, International Communication Association, Albuquerque 1995. 
- szybkie przejście pomiędzy jednostką aktywną, przywódczą i destrukcyjną;

- pozorną lub rzeczywistą anonimowośćć ${ }^{41}$.

Z drugiej strony społeczności wirtualne mają możliwości pokonywania naturalnych barier (np. odległość między pracą a miejscem zamieszkania), a nawet tworzenia w sieci wspólnot wykraczających poza granice państw. W ten sposób mogą one uzupełniać społeczności w sytuacjach, kiedy z różnych przyczyn ich nieskrępowane funkcjonowanie w świecie realnym jest utrudnione. Społeczności wirtualne pozwalają na afirmacje niektórych form wspólnotowości, które nie mogłyby ujawnić się w innych formach organizacji społecznej, np. mniejszości, których członkowie za względów kulturowych, obyczajowych czy prawnych nie mogą utrzymywać otwartych więzi społecznych. Społeczności te cechują takie wartości, jak wolność wypowiedzi, równość i otwarty dostęp, które sprzyjają procesom demokratycznym i debacie publicznej.

Sprzeczne oceny rzeczywistości powstającej w społecznościach wirtualnych wynikają z dwuznacznego charakteru samej istoty procesów globalizacji, które nie dają się ująć w jedną formułę, skazując badaczy na aspektowość i partykularyzm ocen. Wielość i różnorodność zjawisk, jakie generuje przestrzeń wirtualna i jej kulturowe aplikacje, nie mieści się w żadnej teorii i wyprzedza w sposób zawstydzający wrażliwość i wyobraźnię teoretyczną badaczy. Konfuzja teoretyczna wynika z naturalnej sprzeczności leżącej w samej rzeczywistości, i to w kilku nakładających się wymiarach:

$\begin{array}{lll}\text { unifikacja } & v s . & \text { różnicowanie } \\ \text { de-terytorializacja } & \text { vs. } & \text { re-terytorializacja } \\ \text { transkulturacja } & \text { vs. } & \text { in-kulturacja } \\ \text { de-konstrukcja } & v s . & \text { re-konstrukcja } \\ \text { dezintegracja } & v s . & \text { re-integracja } \\ \text { homogenizacja } & \text { vs. } & \text { hybrydyzacja }\end{array}$

Obie strony powyższego schematu ukazują równie realne aspekty rzeczywistości globalizujących się społeczeństw, w których procesy wirtualizacji odgrywają bardzo istotną rolę. Sprzeczności te w całej rozciągłości odnoszą się także do dynamiki kultur narodowych, której to transformacji nie sposób dzisiaj zrozumieć poza intensywnymi procesami medializacji.

W nowej przestrzeni obecności człowieka komunikacja i wspólnotowość etniczna zmieniają swoje klasyczne formy, które przejmują cechy społeczeństwa informacyjnego. Zmieniają się narzędzia przekazu wartości i symboliki etnicznej, rozdzielające kategorie terytorium i przestrzeni etnicznej. Ta ostatnia staje się bardziej transgresyjna, mobilna i polimorficzna. Poszczególne przestrzenie etniczne coraz łatwiej i częściej nakładają się na siebie, stając się w istocie wieloetnicznymi, i znajdują wiele nowych pól synergii. Zmieniają się formy dostępu i przekazu rdzennych wartości kultur etnicznych oraz wzrasta znaczenie umiejętności interakcji międzykulturowych. Powstają w tej sytuacji pytania: co określa granice kultur etnicznych?, jak zmienia się sama etniczność w warunkach przestrzeni wirtualnej?, czy zapośredniczenie interakcji osłabia doświadczenie wspólnoty etnicznej i charakteryzujących je więzi?, do jakiego stopnia komunika-

$41 \quad$ S. Jaskuła, Общества в новом... 
cja wewnątrz społeczności etnicznej podlega procesom dekontekstualizacji i upraszcza jej język?, jak zmienia się kultura symboliczna społeczności etnicznych i narodowych?, w jaki sposób zmiany te przenoszą się na przekształcenia osobowości kulturowej ich członków?, w jakim zakresie przestrzeń wirtualna wymusza na nas przeformułowanie wielu klasycznych koncepcji w analizie problematyki etnicznej, jak np. pojęcia centrum i peryferii kultury narodowej? ${ }^{32}$.

\section{KU NOWEMU ROZUMIENIU GRUPY ETNICZNEJ}

Współczesny zglobalizowany świat pozornie wszystko ujednolica i standaryzuje. Wielokrotnie jest to jednak złudzenie, a waga, jaką ludzie przywiązują do swoich narodowych, etnicznych czy nawet grupowych identyfikacji, jest zadziwiająca. Można wskazać elementy cywilizacyjnej codzienności, stylu życia i zachowań konsumpcyjnych, które na całym świecie wyglądają niemal identycznie, jednak ludzie nie stają się tacy sami, ich systemy wartości nie standaryzują się w sposób, jaki wydawał się niemal pewny jeszcze w latach 70. ubiegłego wieku. Różnice kulturowe między narodami i grupami społecznymi utrzymują się i przenoszą w rzeczywistość wirtualną, choć nie dokonuje się to bez istotnych zmian w sposobie ich doświadczania i wielu fundamentalnych funkcjach. Opis, a jeszcze bardziej rozumienie i wyjaśniane tych zjawisk rodzi jednak zupełnie nowe problemy teoretyczne i analityczne. Zmuszają one do istotnej redefinicji wielu podstawowych terminów i pojęć, jak pojęcie grupy i kultury etnicznej, a następnie grupy i kultury narodowej, stanowiących o standardach konceptualnych nauk społecznych i humanistycznych. Dzieje się tak ze względu na konsekwencje integracji przestrzeni klasycznej i wirtualnej poprzez wspomniane już wcześniej procesy de-terytorializacji, de-chronologizacji i de-personalizacji.

Dotychczasowe rozumienie grupy etnicznej ściśle nawiązywało do terytorium, w którym ona przebywała, tworzyła i kumulowała wszystko, co miało znaczenie nie tylko praktyczne, ale też w równiej mierze symboliczno-magiczne. Cechę tę w jej różnorodnych uwikłaniach analizuje Antonina Kłoskowska w swojej książce Kultury narodowe u korzeni ${ }^{43}$. Koncepcja Kłoskowskiej, zwana teoria syntagmy kultury narodowej, pozwala w łatwy sposób wkomponować w jej system wyjaśniania działanie procesów wirtualizacji i ukazać efekty ich wpływu na kierunek procesów sensotwórczych, które mogą być także okreslone jako logotwórcze dynamizmy kultury ${ }^{44}$.

Pomimo wielości form, stopnia integracji, jak też rozmaitych dynamizmów rozproszenia grup etnicznych poprzez współczesne procesy migracyjne Kłoskowska przyjmuje, iż: Pierwotna, tradycyjna zbiorowość etniczna, czyli grupa etniczna, to mata spotecz-

42 L. Korporowicz, Tożsamości kulturowe u korzeni, [w:] Kultura jako pamięć. Posttradycjonalne znaczenie przesztości, red. E. Hałas, Kraków 2012; tenże, Senskultury, [w:] Horyzonty kultury. Pomiędzy ciagtościa a zmiana, red. R. Wiśniewski, M. Szupejko, Warszawa 2012.

43 A. Kłoskowska, Kultury narodowe u korzeni, Warszawa 2005.

44 L. Korporowicz, Logotwórcze dynamizmy kultury, „Studia Socjologiczne” 1989, nr 3, s. 109-131. 
ność powiązana ściśle z terytorium, które ma dla niej znaczenie nie tylko praktyczne, jako podstawa bytu, ale także symboliczno-magiczne. Jest to grupa bezpośrednich nawykowych styczności, powiązana związami sąsiedzkimi [...] Jej cztonkom brak świadomości historycznej i samorefleksji, ale ze względu na bliskość kontaktów i nawykowy charakter podobieństwa zachowań stanowia oni ścista wspólnotę ${ }^{45}$.

Dalszy rozwój cywilizacji, „odczarowanie” świata magicznego, ale i rozwój kultury symbolicznej wraz z procesami jej instytucjonalizacji, autonomizacji, a przede wszystkim pojawienie się organizmów państwowych wygenerowały znacznie bardziej dojrzałe byty kultur narodowych o zupełnie nowej funkcji przestrzeni kulturowej, także w relacjach międzynarodowych i ponadnarodowych, wspomaganych nowymi zdobyczami technologii komunikowania, przekraczania granic fizycznych i zjawiskami o charakterze transnarodowym. Nie oznacza to naturalnie - pisze Kłoskowska - że sfera symboliczna odgrywa mata role w pierwotnych grupach etnicznych. W nich wtaśnie wszystko - lub prawie wszystko - jest przepojone symbolizmem, ale czynnik ten sięnie autonomizuje i nie odrywa się od sfery bytu lub „rzeczywistości” $w$ takim stopniu, jak czysto autoteliczna kultura wyspecjalizowanych dziedzin życia rozwiniętych spoteczności narodowych. Te wtaśnie dziedziny maja szczególne, co nie znaczy, że wytączne, znaczenie dla zapewnienia „wspólnoty komunikowania", która stanowi istotę narodu $[. . .]^{46}$.

Nowa wspólnota komunikowania powstaje przy rosnącej obecności przestrzeni wirtualnej, która w automatyczny sposób dowartościowuje znaczenie kultury symbolicznej, ale jej działanie niekoniecznie wspiera procesy wspólnotowe, a wręcz przeciwnie - dywersyfikuje uniwersum świata symbolicznego. $Z$ jednej strony mamy więc liczne procesy „odrywania” nowych treści kultury i nadawania im znaczenia w szerszym wymiarze kultury narodowej, z drugiej jednak strony proces ten wykazuje się dużą chaotycznością, dekontekstualizacją i rozproszeniem ${ }^{47}$. Dlatego też nowe rozumienie zarówno grupy, jak i tworzonej przez nią kultury w znacznie większym stopniu uwzględniać musi nie tylko to, co było podstawą tworzenia pierwotnych grup etnicznych, jak niezapośrednioczony kontakt i związek z konkretnym terytorium, ale i więziotwórcze procesy symboliczne. Problemem etycznym z pewnością pozostanie kwestia godności osoby i grupy, która w zdepersonalizowanej przestrzeni kultury powróci ze wzmożoną siłą ze względu na jej fundamentalne zagrożenia. Przeakcentowanie klasycznych komponentów rozumienia grupy etnicznej we wskazanym powyżej kierunku widać w strukturze rozumienia grupy etnicznej, jaką proponuje Ewa Nowicka, stwierdzając, iż grupa [...] sama siebie uważa za odrębna od innych grup i jest uważana przez inne grupy za odrębna pod czterema względami: 1. kultury (jezzyka, religii itd.), 2. genealogii pojmowanej w kategoriach wspólnoty biologicznej czy rasowej albo losów historycznych, 3. cech osobowości określanych taccznie jako charakter narodowy czy etniczny, 4. zajmowanego terytorium ${ }^{48}$.

45 A. Kłoskowska, Kultury narodowe..., s. 19.

46 Tamże, s. 33.

47 S. Wilson, L. Peterson, The Anthropology of the Online Communities, „Annual Review of Anthropology” 2002, Vol. 31.

48 E. Nowicka, Etniczność a sytuacja mniejszościowa, „Przegląd Polonijny” 1989, R. 15, z. 1, s. 44. 
Zestawiając cechy klasycznego i zrekonfigurowanego - poprzez działanie przestrzeni wirtualnej - sposobu istnienia grupy, można zauważyć kierunek zmian zachodzących w charakterystyce kulturotwórczego funkcjonowania nowych grup społecznych, który to sposób umownie nazwać możemy konstruktywistycznym ze względu na „sztucznie”, tzn. cywilizacyjnie wytworzone warunki ich powstawania.

Tabela 1. Sposoby klasycznego i konstruktywistycznego istnienia grup kulturowych

\begin{tabular}{|c|c|}
\hline Grupy w rozumieniu klasycznym & Grupy w rozumieniu konstruktywistycznym \\
\hline Duże znaczenie terytorium & Procesy postępującej deterytorializacji \\
\hline $\begin{array}{l}\text { Bezpośredni kontakt jednostek i wysoki poziom } \\
\text { personalizacji relacji międzyosobowych }\end{array}$ & $\begin{array}{l}\text { Pośredni kontakt jednostek i depersonalizacja } \\
\text { relacji zapośredniczonych medialnie }\end{array}$ \\
\hline Stałe struktury społeczne & Płynne struktury społeczne \\
\hline Komunikacja jako przekaz i oddziaływanie & Komunikacja jako interakcja \\
\hline Więzi społeczne dziedziczone & $\begin{array}{l}\text { Więzi społeczne wybierane, modyfikowane } \\
\text { i konstruowane }\end{array}$ \\
\hline $\begin{array}{l}\text { Kontrola społeczna poprzez skonwencjonalizo- } \\
\text { wane wzory zachowań }\end{array}$ & $\begin{array}{l}\text { Indywidualizacja form uczestnictwa w kulturze } \\
\text { i przestrzeni informacyjnej } \\
\text { Wielowariantowe modele tożsamości kulturowej } \\
\text { o charakterze hybrydalnym } \\
\text { Rosnąca rola umiejętności projektowania kariery } \\
\text { zawodowej i stylów życia }\end{array}$ \\
\hline Pierwotne grupy etniczne & Wtórne grupy etniczne i narodowe \\
\hline
\end{tabular}

Źródło: opracowanie własne.

Procesy wirtualizacji kultur narodowych pogłębiają zmiany, jakie dokonały się w nich znacznie wcześniej wraz z rozwojem nowych środków komunikowania i różnorodnej transgresji wielu granic, które przyniosły problem hybrydyzacji, różnicowania wewnętrznego, wielokulturowości, a nawet atrofii kultur. Nie ulega jednak wątpliwości, iż przestrzeń wirtualna wnosi w dynamikę zmian, jakim podlegają kultury narodowe i etniczne, bardzo intensywne rekompozycje w strukturze wartości i znaczeń. Konfiguracje te, jako konsekwencja swoistych wyborów dokonanych przez poszczególne kultury narodowe, traktowane jako quasi-podmioty i nazwane przez Kłoskowską syntagma kultury narodowej ${ }^{49}$, uzupełnić trzeba o kolejny, dynamiczny komponent. Są nimi właśnie procesy wirtualizacji, które wnoszą w konfigurację kultury narodowej

49 Metaforycznie więc tylko traktowane pojęcie syntagmy ma uzmystowic zwiąki zachodzace pomiędzy poszczególnymi systemami kultury tej samej zbiorowości narodowej. Spośród wielu innych wspólnot kulturowych, takich jak grupy celowe, kategorie zawodowe, a nawet klasy spoteczne, zbiorowości narodowe i etniczne wyróżniają się wielością i ztożonością elementów swoich kultur. Ten sam fakt uzasadnia potrzebę poszukiwania wewnętrznego związku tączacej je kultury [...] Syntagmy kultury narodowej - inaczej niz jezykowej - nie można jednak traktować zbyt sztywno [...] Zjawiska etnicyzacji nie zaprzeczaja jednak 
(syntagmę) zupełnie nowe treści i nowe dynamizmy ${ }^{50}$. Istotę procesów, jakie tworzą syntagmę kultury narodowej, przedstawia poniższy schemat.

Rysunek 1. Wirtualizacja kultury w syntagmie kultur narodowych

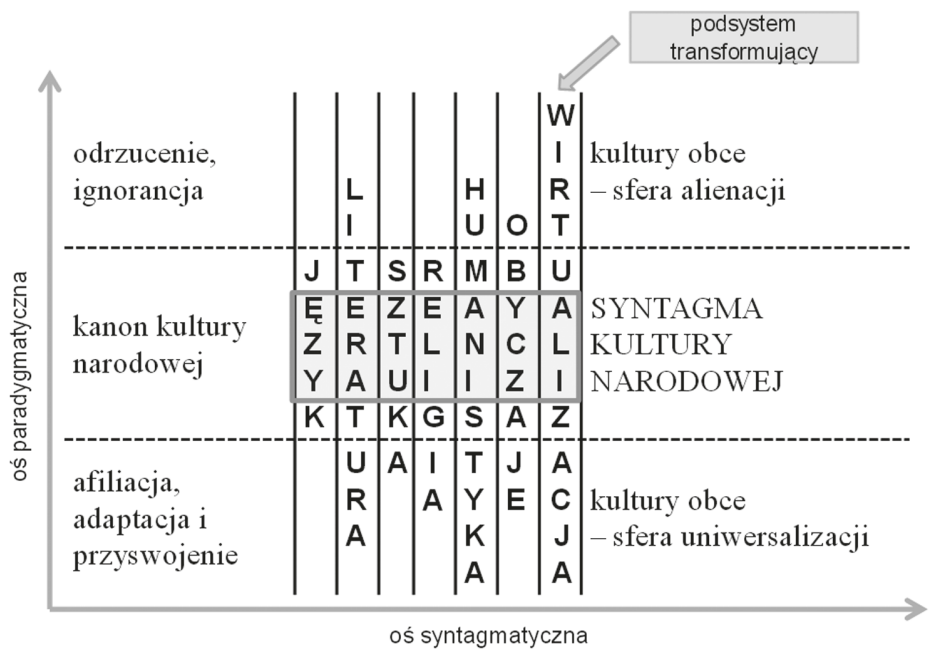

Źródło: opracowanie własne na podstawie schematu A. Kłoskowskiej, Kultury narodowe u korzeni, Warszawa 2005, s. 37.

Kultury narodowe, jak pokazuje powyższy schemat, stoją więc dzisiaj przed wielkim wyzwaniem wkomponowania procesów wirtualizacji jako systemów transformujących w całokształt ich kulturowej syntagmy, równoważąc procesy poszerzania jej zakresu i treści, w równej jednak mierze stając przed wyzwaniem zagubienia w nadmiarze i chaosie możliwości, dekompozycji i ustawicznej metamorfozy. Procesy wirtualizacji stają się stałym komponentem syntagmy kulturowej, określając jej faktyczny charakter i kierunek przekształceń. W istocie poszerzają one możliwy zakres owej syntagmy, daleko odbiegając od dotychczasowych kanonów konkretnej kultury narodowej, etnicznej lub nawet kanonów mniejszych grup kulturowych, tworząc synergie „realności” i wirtualności o nieznanych do tej pory formach, treściach i konfiguracjach. Syntagmy te tworzą się w nowych diasporach komunikacyjnych, nadając im spoistość, ale i odrębność, tożsamość, ale i płynność ${ }^{51}$. Stanowią one nową „realność” przestrzeni wirtualnej, w której

istnieniu podobieństw zblizajacych do siebie kultury narodowej i dziatajacych w kierunku uniwersalizacji przekraczajacej granice syntagmy - A. Kłoskowska, Kultury narodowe..., s. 38.

50 L. Leung, Virtual Ethnicity. Race, Resistance and the World Wide Web, Aldershot 2005.

51 K. Diamandaki, Virtual Ethnicity and Digital Diasporas: Identity Construction in Cyberspace, „Global Media Journal” 2003, Vol. 2, nr 2, [online] http://lass.purduecal.edu/cca/gmj/sp03/graduatesp03/ gmj-sp03grad-diamandaki.htm, 10 III 2013; K. Fink, Burma: Constructive Engagement in Cyberspace?, „Cultural Survival Quarterly” 1997, Vol. 21, nr 4, [online] https://www.culturalsurvival. org/ourpublications/csq/article/burma-constructive-engagement-cyberspace, 10 III 2013. 
kultura symboliczna ujawnia swoje kreatywne możliwości, także w obszarze kultury narodowej i etnicznej, niezależnie od sposobu ich odróżnienia. Procesy ich wirtualizacji ukazują też potrzebę nowego typu refleksji, którą podjąć musi współczesna antropologia, socjologia, pedagogika, psychologia kulturowa oraz wiele nauk humanistycznych, szczególnie studia kulturowe jako poszerzony rodzaj kulturoznawstwa. Analiza wytworów będących efektem syntagmy kultury etnicznej i narodowej w warunkach cywilizacji medialnej nie mieści się bowiem w żadnej klasycznej dyscyplinie nauki. Nakazuje jednocześnie mówić o czymś więcej niż nowym, ale ciągle ściśle określonym i uporządkowanym arsenale zmodernizowanych nauk.

\section{ZAKOŃCZENIE}

Rozwój nowych technologii we współczesnym świecie prowadzi nieuchronnie do głębokich zmian w strukturze społecznej, kulturze, systemie wartości i norm będących spoiwem społeczeństw. Ilość, jakość i złożoność zmian zachodzących we współczesnym świecie ze względu na niespotykaną dotąd intensywność jest określana mianem „wielkiego wstrząsu".

Nie sposób nie zgodzić się z tezą McLuhana, że otoczenie techniczne ma decydujący wpływ na ludzi, ich zachowania i postawy. Wspomniana już w tekście, a stworzona przez Manuela Castellsa metafora współczesności jako „galaktyki Internetu” jest tylko jednym z wielu powszechnie używanych określeń świata, w którym żyjemy. Obok niego możemy również znaleźć ponowoczesność, społeczeństwo wiedzy, społeczeństwo ryzyka, późną nowoczesność czy też społeczeństwo informacyjne. Ciągły wzrost ilości dostępnych informacji (często połączony ze spadkiem ich jakości) wprowadza w ludzkie umysły zamęt i, być może nieco paradoksalnie, utrudnia proces uniwersalizacji cyberkultury ${ }^{52}$.

Zmieniający się szybko charakter współczesnej cywilizacji zmusza do przewartościowania wielu systemów zachowań, a nade wszystko schematów myślenia, kształtowania umiejętności i postaw. Sytuacja ta w pełni dotyczy wszystkiego, co konieczne jest do sprostania wymogom, kluczowej dla rozwoju społecznego i gospodarczego, nowej przestrzeni informacyjnej, komunikacyjnej, kulturowej i międzykulturowej. Dzieje się to poprzez wyzwanie, jakim jest potrzeba zupełnie nowego rozumienia kultur narodowych w procesie wirtualizacji. Zmianie ulec musi sam sposób ich pojmowania, wykształcony w dobie względnej stabilności i mniejszego zakresu transformacji systemowych. Kierunek zmian wyznacza potrzeba większej elastyczności, innowacyjności, kreatywności i transgresyjności kultur, które mają nie tyle przysposobić, co uwrażliwić, nie tyle wykształcić, co zainspirować, nie tyle zaadaptować, co ukierunkować ku wyzwaniom coraz mniej przewidywalnych i diagnozowalnych warunków życia i pracy współczesności. W tym celu opracować należy nową nie tyle teorię grupy, ile samego procesu socjalizacji, tożsamości, więzi społecznych w warunkach sieciowego zapo-

52 P. Delvy, Drugi potop, „Magazyn Sztuki” 1997, nr 13, [online] http://magazynsztuki.eu/old/ archiwum/nr_13/perre_delvy_2potop.htm, 14 III 2013. 
średniczenia, teleobecności człowieka w polisferycznym modelu cywilizacji medialnej. Kierunki tych poszukiwań wyznaczyć mogą następujące tezy:

- Teza 1: Kultury narodowe są pewną formą integracji wybranych elementów wielu systemów o charakterze coraz bardziej otwartym.

- Teza 2: „Syntagmy” kultury narodowej w procesie wirtualizacji nie należy traktować zbyt sztywno. Elementy systemów, nawet jednolitych w swej genezie, ulegają bowiem transetnicyzacji, wchodząc w obręb innych kultur.

- Teza 3: Przestrzeń wirtualna przybliża do siebie różne kultury narodowe, działając w kierunku wymiany i synergii kulturowej.

- Teza 4: Przestrzeń wirtualna z jednej strony może ułatwiać i przyspieszać rozwój symbolicznego uniwersum kultury narodowej, a z drugiej strony może prowadzić do jej nadmiernej transnarodowej dywersyfikacji i rozmywać konstytuujące ją subsystemy wartości rdzennych.

\section{BIBLIOGRAFIA}

Barney D., Spoteczeństwo sieci, przeł. M. Fronia, Warszawa 2008, Key Concepts.

Baudrillard J., Precesja symulakrów, [w:] Postmodernizm. Antologia przektadów, red. R. Nycz, Kraków 1998.

Bauman Z., Ptynne życie, przeł. T. Kunz, Kraków 2007.

Bendyk E., E-learning, zerwanie z tradycja humanizmu?, „E-mentor” 2009, nr 1, [online] http://www.e-mentor.edu.pl/artykul/index/numer/28/id/606.

Castells M., Galaktyka Internetu. Refleksje nad Internetem, biznesem i spoteczeństwem, przel. T. Hornowski, Poznań 2003, Nowe Horyzonty.

Castells M., Kwestia miejska, przeł. B. Jałowiecki, J. Piątkowski, Warszawa 1982.

Castells M., Sita tożsamości, przeł. S. Szymański, Warszawa 2009, Wiek informacji, t. 2.

Castells M., Spoteczeństwo sieci, przeł. M. Marody i in., Warszawa 2007, Wiek informacji, t. 1.

Castells M., Wtadza komunikacji, przet. J. Jedliński, P. Tomanek, Warszawa 2013.

CyberSociety 2.0. Revisiting Computer-Mediated Communication and Community, red. S.G. Jones, Thousand Oaks 1998, New Media Cultures, 2.

Delvy P., Drugi potop, „Magazyn Sztuki” 1997, nr 13, [online] http://magazynsztuki.eu/old/ archiwum/nr_13/perre_delvy_2potop.htm.

Diamandaki K., Virtual Ethnicity and Digital Diasporas: Identity Construction in Cyberspace, „Global Media Journal” 2003, Vol. 2, nr 2, [online] http://lass.purduecal.edu/cca/gmj/ sp03/graduatesp03/gmj-sp03grad-diamandaki.htm.

Drucker P., The Age of Discontinuity. Guidelines to Our Changing Society, New Brunswick 1992. Fernback J., Thompson B., Computer-Mediated Communication and American Collectivity. The Dimensions of Community Within Cyberspace, International Communication Association, Albuquerque 1995.

Fink Ch., Burma: Constructive Engagement in Cyberspace?, "Cultural Survival Quarterly” 1997, Vol. 21, nr 4, [online] https://www.culturalsurvival.org/ourpublications/csq/article/ burma-constructive-engagement-cyberspace. 
Giddens A., Nowoczesność i tożsamość. „Ja” i spoteczeństwo w epoce późnej nowoczesności, przeł. A. Szulżycka, Warszawa 2007, Biblioteka Socjologiczna.

Goban-Klas T., Ontologia Internetu, [w:] Spoteczeństwo informacyjne. Wizja czy rzeczywistośc? II ogólnopolska konferencja naukowa, t. 1, red. L.H. Haber, Kraków 2004.

Heidegger M., Bycie i czas, przeł. B. Baran, Warszawa 2004, Biblioteka Wspótczesnych Filozofów. Heim M., The Erotic Ontology of Cyberspace, [w:] Cyberspace. First Steps, red. M. Benedikt, Cambridge (Mass.) 1991.

Hołyst B., Zagrożenia tadu spotecznego, t. 1, Warszawa 2013.

Jaskuła S., Intercultural Space. Contemporary Challenges and Perspectives, [w:] Poland - Jordan - European Union: Future Aspects. Conference, December 15, 2010, red. S. Abudayeh, K. Bojko, Amman 2011.

Jaskuła S., New Forms of Mobility in the Word of Virtualization and Medialization of Cultures, „Politeja” 2012, nr 20/1: Mobility of Cultures.

Jaskuła S., Общества в новом информационном пространстве, „Міжнародний науковий форум: соціологія, психологія, педагогіка, менеджмент” 2010, $\mathrm{nr} 2$.

Jaskuła S., Piaty wymiar w edukacji międzykulturowej, [w:] Poza paradygmaty. Pedagogika międzykulturowa. Ksiega pamiątkowa dedykowana profesorowi Tadeuszowi Lewowickiemu, t. 2, red. A. Szczurek-Boruta, E. Ogrodzka-Mazur, Toruń 2012.

Jaskuła S., Symbioza i odrębność dwóch światów, „Politeja” 2012, nr 20/2: Wspótczesna przestrzeń tożsamości.

Jaskuła S., Tożsamość a piąty wymiar w przestrzeni międzykulturowej, [w:] Tożsamość w wielokulturowym kontekście, red. L. Dyczewski, K. Jurek, Lublin 2013, Tożsamość Osób, Zbiorowości, Instytucji, 13.

Kanter R., Co powiedziatby Peter Drucker?, „Harvard Business Review Polska” XI 2009.

Kerckhove D. de, Przeciw architekturze (architektura inteligencji), [w:] Kody McLuhana. Topografia nowych mediów, red. A. Maj, M. Derdy-Nowakowski, Katowice 2009, Medioznawstwo.

Kłoskowska A., Kultury narodowe u korzeni, Warszawa 2005.

Korporowicz L., Logotwórcze dynamizmy kultury, „Studia Socjologiczne” 1989, nr 3.

Korporowicz L., Polimorficzna przestrzeń tożsamości, „Politeja” 2012, nr 20/2: Wspótczesna przestrzeń tożsamości.

Korporowicz L., Sens kultury, [w:] Horyzonty kultury. Pomiędzy ciagtościa a zmiana, red. R. Wiśniewski, M. Szupejko, Warszawa 2012.

Korporowicz L., Socjologia kulturowa. Kontynuacje i poszukiwania, Kraków 2011.

Korporowicz L., Tożsamości kulturowe u korzeni, [w:] Kultura jako pamięć. Posttradycjonalne znaczenie przesztości, red. E. Hałas, Kraków 2012.

Leung L., Virtual Ethnicity. Race, Resistance and the World Wide Web, Aldershot 2005.

Lévy P., Collective Intelligence: A Civilisation, przeł. C. Bell, „Crossings: eJournal of Art and Technology” 2001, Vol. 1, nr 1, [online] http://crossings.tcd.ie/issues/1.1/Levy/.

Macfadyen L., Virtual Ethnicity: The New Digitization of Place, Body, Language, and Memory, „Electronic Magazine of Multicultural Education” 2006, Vol. 8, nr 1, [online] http://www. eastern.edu/publications/emme/2006spring/macfadyen.pdf.

McLuhan M., Fiore Q., War and Peace in the Global Village. An Inventory of Some of the Current Spastic Situations that Could Be Eliminated by More Feedforward, New York 1968. 
Mihir F., Virtual Ethnicity: A Study on Ethnicity \& Technology Usage, „Proceedings of Society for Information Technology and Teacher Education International Conference" 2009, Vol. 40, nr 4 .

Mitchell W., City of Bits. Space, Place and the Infobahn, Cambridge (Mass.) 1995.

Mitchell W., E-topia. „Urban Life, Jim - But Not as We Know It”, Cambridge (Mass.) 1999.

Nowicka E., Etniczność a sytuacja mniejszościowa, „Przegląd Polonijny” 1989, R. 15, z. 1.

Ong W., Oralność i piśmienność. Stowo poddane technologii, przeł. J. Japola, Lublin 1992.

Pagels H., Perfect Symmetry. The Search for the Beginning of Time, New York 1985.

Pankowska K., Rzeczywistość zapośredniczona - nowe problemy wzrastania dziecka w przestrzeni medialnej, [w:] Media elektroniczne - kreujace obraz rodziny i dziecka, red. J. Izdebska, Białystok 2008.

Poster M., Information Please. Culture and Politics in the Age of Digital Machines, Durham 2006. Poster M., The Second Media Age, Cambridge 1995.

Poster M., What's the Matter with the Internet?, Minneapolis 2001, Electronic Mediations, 3.

Rheingold H., The Virtual Community. Homesteading on the Electronic Frontier, Reading 1993.

Turkle S., Life on the Screen. Identity in the Age of the Internet, New York 1995.

Urry J., Socjologia mobilności, przet. J. Stawiński, Warszawa 2009, Socjologia Wspótczesna.

Wilson S., Peterson L., The Anthropology of the Online Communities, „Annual Review of Anthropology" 2002, Vol. 31.

Zurawski N., Ethnicity and the Internet in a Global Society, 1996, [online] http://www.isoc.org/ inet96/proceedings/e8/e8_1.htm.

Dr Sylwia JASKUŁA - doktor pedagogiki, autorka wielu publikacji z dziedziny kultury i teorii przestrzeni międzykulturowej, transformacji i społecznych wyzwań edukacji, ewaluacji rozwojowej, społeczeństwa sieci oraz kompetencji informacyjno-komunikacyjnych w kontekście globalnych i lokalnych zmian tożsamości kulturowej. Animatorka badań porównawczych nad społeczeństwem informacyjnym w warunkach przemian rynkowych i kulturowych oraz badań nad nowymi formami społeczeństwa wiedzy. Autorka strategii rozwojowych, programów szkoleniowych i badawczych w dziedzinie ewaluacji w edukacji.

Dr hab. Leszek KORPOROWICZ - socjolog, pracownik naukowo-dydaktyczny Instytutu Studiów Międzykulturowych Wydziału Studiów Międzynarodowych i Politycznych UJ. Obszar jego zainteresowań naukowych i badawczych obejmuje zasadniczo analizę kultury i antropologii symbolicznej, socjologię komunikowania, kompetencji i przestrzeni międzykulturowej, socjologię języka i dziedzictwa kulturowego, a także zarządzanie międzykulturowe, socjologię edukacji, społeczeństwo wiedzy, socjologię tożsamości, osobowości i zmian kulturowych oraz teoretyczną i praktyczną problematykę nowych w Polsce studiów ewaluacyjnych. Zagadnienia te analizowane są w perspektywie socjologii humanistycznej i socjologii interpretatywnej. Zasadniczym polem prowadzonych przez niego analiz jest obecna w doświadczeniu człowieka kultura, traktowana nie jako system zachowań, ale jako obdarzony sensem, intencjonalny obiekt zaangażowania o silnych aspektach aksjologicznych. 